\title{
ウイリアム・ヘイプニー著『当世建築業者の手引き』の検討 A STUDY ON WILLIAM HALFPENNY'S MODERN BUILDER'S ASSISTANT OF 1757
}

\author{
星 和 彦* \\ Kazuhiko HOSHI
}

\begin{abstract}
William Halfpenny's Modern Builder's Assistant of 1757 was fundamentally published as pattern-book of various kinds of buildings, houses for a country seat in particular. In the first part of the book, he translated a part of the first book of Andrea Palladio's I Quatro Libri. The second and third parts of the book are a collection of drawings of buildings and architectural details by four designers including W. Halfpenny. On the basis of the stylistic analysis of his translation and the proportional study of drawings of buildings, the Modern Builder's Assistant exactly and vividly reflects the trend and transition of En. glish architecture in the $1750 \mathrm{~s}$.
\end{abstract}

Keyword: William Halfpenny, Modern Builder's Assistant, pattern-book, the eighteenth century, England ウィリアム・ヘイプニー 当世建築業者の手引き 建物雛型集 18 世紀 英国

\section{はじめに}

ウィリアム・ヘイプニー (William Halfpenny, -1755)は、英国の 18世紀前半に活動した建築家、建築著述家として知られる。建築 作品に著名なものを残していない一方、著作は少なくとも21が数 えられ、実務または建築設計よりもむしろ著述活動で活発な動き をみせたといえよう。しかし同時期の建築著述家として、へイプニ 一とならび名をあげられるロバート・モリス (Robert Morris, 1701-54）やバティ・ラングリ（Batty Langley, 1696-1751）がもっ ぱら著作に専念したのに対して、ヘイプニーは実務建築家としても 仕事をしており、著述活動はその時期の前後に別れて展開された点 がモリスらとは異なっている2。

本稿で取りあげる『当世建築業者の手引き』（ロンドン，1757） は、この著述第二期（1749年以降）に属するだけでなく、へイプニ 一の死後に出版された ${ }^{3}$ 。本書は、正式には『当世建築業者の手引 き、あるいは建築術の全体系の簡明な要約』と書名が与えられ、本 文52頁、図版85枚からなる小型二つ折れ本である（なお本稿では 『当世建築業者の手引き』と略記する）。内容は3 3 部にわかれてい る。第一部はアンドレア・パラーディオの『建築四書』（1570） からの部分的な翻訳である。他方、第二部、第三部は図版と解説か ら構成され、このうち第二部は建物設計案の集成で、第三部は建築
的細部の図面集からなっている。

本稿は、まず第一部のパラーディオの翻訳を、当時を代表するア イザック・ウエア（Isaac Ware, -1766）による翻訳（1738）“と比 較・検討して、本書の翻訳の特徴を探る。ついで、第二部の建物設 計案、第三部の細部図面集の概要をまとめ、このうち設計案につい ては、その記述内容を整理して、その特色を検討する。さらに、第 二部の設計案に関して、建物を構成する諸室の平面に着目し、抽出 できる比例の傾向、建物種別や部屋と比例の関係、また設計者と採 用した比例について検討を加える。こうして、本書の特徴と、その 18世紀中頃における出版の意味について考究することが、本稿の 目的である。

\section{§ 1. パラーディオの翻訳に関する検討}

『当世建築業者の手引き』の第一部は7章から成る。第 1 章は 「古代人の用いた建築の 5 種のオーダーについて」、第 2 章は「円 柱のすぼめかたと直径の縮減について、ならびに柱間間隔、片蓋柱 について」で、第3章からはトスカナ式からコンポジット式までの 各種オーダーの記述となっている。この部分はパラーディオの著し た『建築四畫』、第一畫第12章から18章のへイプニーによる翻訳 で、建築のオーダー全般と各種オーダーについて解説された部分に

本稿は，1997年度日本建築学会関東支部研究報告集に発表したものをもとに，さらに知見を梁めたものである。

* 前橋工科大学工学部建築学科 助教授. 工博 Assoc. Prof., Department of Architecture Faculty of Technology, Maebashi Institute of Technology, Dr. Eng. 
当たる。ヘイプニーでは図版に銅板の凸版印刷が採用され、眓版内 容は『建築四書』と同じだが、線が克明で表現自体はより鮮明とな っている5。ここでは、へイプニーの翻訳の特徴を検討するため、 パラーディオ主義期であった当時の代表的な訳本といえるウエア版 と比較してみよう。

まず、へイプニ一は原著にならい、細かく段落にわけることなく 訳しており、頻繁に段落に分割することを特徴としたウエアとはの、 この点で異なる。また、固有名詞でない場合も名詞の頭文字がほと んど大文字で始められ、さらに建築に関わる用語ではイタリック体 とされることもあった。ヘイプニーがイタリック体とした用語をみ ると、使い分けに意図や規則性が与えられているように思われる。 例えば、つねにあるいはほぼイタリック体とするのは、Column、 Module、Profile の三つの単語と、あるいはPedestal、Base、Astragal、Cavetto、Cymatium、Metopeなどのオーダーの部位や部 材を示す単語であった。一方、Architecture、Proportionなど建築 に関する概念的な用語や、Architect 、Buildingなどの具体的でよ く使われる用語はイタリック体としていない。こうした使い分けを まとめてみると、実際にオーダーの構成を規定したり、オーダーを 形成するうえで重要な用語は、ほとんどの場合、イタリック体とし ていた。また、同じ単語でも、文脈上肝要とみなされた場合、やは クイタリック体にされている。例えば、orderという用語は、「建 築のオーダー」の意味として使われると、オーダー全般が対象の章 ではOrder で、トスカナ式の章でのみOrder とされる。一方、 「階」として使われるときは、つねにOrderである。個々のオーダ 一の解説でトスカナ式のときのみイタリック体としたことには、ト スカナ式が最初に考案されたオーダーという捉えかたと、解説され る第一番目のオーダーという意識の表れと考えられる。またIntercolumniation を、各種オーダーの節で具体的に柱間間隔の寸法を 言及するときはイタリック体としているのも、この例である。こう した名詞の記述方法はウエアでは採られていない。したがって、使 い分けに必ずしも厳格といえない場合もあるが7、ヘイプニ一の特 色として妥当である。

さらに、ヘイプニーには建築用語を、対応する訳語がある場合、 イタリア語を使わずに、極力英語にしようとする指向がみられる。 例えば、コーニスのキューマティウム、礎盤の台石、円柱の柱身下 部の縁輪、小玉縁という剞形の場合、Cymatium、Plinth、Cincture、Astragalとへイプニーは英語で表記する ${ }^{8}$ 。ウエアでは、キ ューマティウムはcimatia、台石はorloとイタリア語がそのまま使 われ、縁輪と小玉縁では、まずcimbia と tondinoがまず当てられ、 ついで英語を記す、伊英併記とされている。ヘイプニーはイタリア 語を使う場合、逆に英語を必ず当てており、例えば、Caulicoli or Stalks などと表現している。これには例外もあり、台石をトスカ ナ式ではOrloとするが、ほかのオーダーではPlinthとしていた。ま た柱頭頸部は、すべてCollarino とされる。しかしこの場合、二回 目にでてきたところでCollarino or Neck と記し、用語の意味と相 当する英語の単語について確認されている 記としては、平縁を意味するlistellaがあった。

ヘイプニーの翻訳はウエアとまったく異なるわけではないが、相 異の明瞭な場合もある。例えば8章の冒頭部分をへイプニーは、

The Ancients had five Kinds of Order of Architecture, viz the
Tuscan, Dorick, Ionick, Corinthian, and Composite. ${ }^{10}$ とする。一方、ウエアでは、

The Tuscan, Dorick, Ionick, Corinthian, and Composite, are the five orders made use of the ancients. "

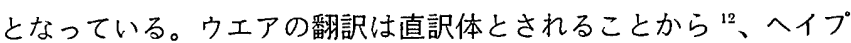
ニ一ではより自然な翻訳となっている部分がみられる。また、第 13章のコリント式オーダーの部分で、柱頭の葉状装飾の割り付け について、ヘイプニーは、

Its Curvature or Diminution, is made by drawing a circular Line from one Horn to the other, and in marking the Point; by which an Equilateral Triangle is made, whose Base is the Diminution. Afterwards a right Line is drawn from Extremities of the above-mentioned Horns, to the Extremity of the Astragal of the Column, which must be made in such a manner, as to be touched touched by the Tips, or Extremities of Leaves, or else come a little more forward; and this will be their Projecture. ${ }^{13}$

と翻訳している。一方、ウエアでは、

The curvature, or diminution, is made by drawing a thread from one horn to the other, and taking the point where the triangle is formed whose base is the diminution, then a line is to be drawn from the extremities of the said horn to the extremity of the astragl or tondino of the column, which line the tip of the leaves is to touch, or they may come out a little more, and this is their projecture. ${ }^{14}$

となっていた。へイプニーでは割り付けの表記などにおける込み入 った表現を緩和しようと試みて、原文を適当に区分する場合もあっ た。さらに語順だけでなく、接続詞や形容詞の使いかたでも、ウエ アとは異なる点をみせており、全体にはわかりやすさに配慮しよう とする指向が読み取れる。

ヘイプニ一の翻訳は記述が段落に分けられておらず、ウエアと は異なり原書に忠実となった反面、必ずしも読みやすいとはいえな い。しかし、直訳をより自然な表現にする箇所がみられた。さらに、 名詞は多くを大文字で始め、とくに建築用語では、へイプニーが重 要な意味をもつ単語とみなした場合にはイタリック体とすることで、 要点の把握を容易とするように考虑したといえる。イタリック体と いう表現方法は、オーダーを論ずるうえで、また理解するために、 ヘイプニーが肝要と捉えていた点を示す結果ともなっていた。

\section{§ 2. 第二部、第三部の図面集成の概要}

『当世建築業者の手引き』の第二部、第三部は図面集成とその解 説からなっているが、第二部は建物を取り扱い、一方、第三部は建 築の装飾的細部などが対象となっている。

第二部は、本文30頁、図版42枚で、どちらも本書全体の半分に 当たり、このへイプニーの著作の中心をなしているといえる。この 部分は、「大家族、あるいは小家族のいる貴顕紳士諸氏、または商 人のための、都市ないし田舎の好みにあわせた、最も簡単明睹で使 いやすい方法による、住宅の平面図、立面図、断面図」 ${ }^{15}$ からなっ ている。採りあげられた例は 36 で、図面に記入された設計者名か ら、著者のヘイプニーのほか、ジョン・ヘイプニー (John Half 
penny, 生没年不詳. 本稿では、J.ヘイプニーと記す）、前述した ロバート・モリス、さらにティモシー・ライトラー (Timothy Lightoler, 1727-69） ${ }^{16}$ が担当している。うちわけはへイプニーが14 と最も多く、J.ヘイプニーが10、モリスとライトラーが6となる ${ }^{17} 。$ ついで、設計案について、記述内容とその順序で、典型的な例を 検討してみよう。ここに採りあげたのは、ヘイプニーによる第 14 案である(図・1 ${ }^{18}$ 。その冒頭は、

「この平面と立面は都市に建つ住宅のためのものである。正面 は62フィート、奥行きは40フィートある。

AA. 正面と裏の階段 ${ }^{19}$ 。幅8 フィート。

B. 玄関広間、幅 11 フィート。

C. 大階段、幅 4 フィート。

D. 裏階段、幅2 フィート 6 インチ。

E. パーラー、17×16フィート。

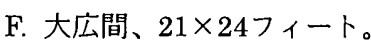

G. パーラー、 $17 \times 24$ フィート。

H. 書斎、11フィート平方。

地下階平面図も載せた図版37の断面図を参照。主要階の点

線位置の断面で、室内の仕上げ方法も描かれている。」

となっている。どの設計案もこのような記述の仕方で始まる。すな わち、まず建物種別または用途が述べられ、敷地の設定が示される こともある。ついで、全体規模に言及され、たいてい1階である主 要階の間取りが、室名と広さから説明される。さらにほかの階の平 面図が載せられ、その階の間取りに説明が加えられるときもある ${ }^{20}$ この場合、解説は続けて、

「A. 階段。幅4 フィート。街路から続く。

B. 通路、幅 11 フィート。

C. 配膡室、 $11 \times 12$ フィート。

D. 裏階段。

E. 執事室、 $17 \times 18$ フィート。

F. 地下室、 $11 \times 12$ フィート。

G. 地下室、 8 フィート 6 インチ $\times 13$ フィート。

H. 地下室、12フィート×13フィート 6 インチ。

I. 管理人室。

J. 厨房、16フィート×24フィート。
この地下階の階高は、内法が8フィート。管理人室、執事室、 配膳室、㴻房は、床面から5フィート6インチまで羽目板張 ク。床は、パーベック石張りのそのほかの家事室はあるが、 欴房を除き板張りで、壁はプラスター仕上げ。」

と、地下階について述べられる。さらに、主要階と2階が、

「主要階と2階は、階高がおのおの14フィートで、広間(F)を 除き、全面的に羽目板張り。広間(F) は、椅子の高さまで羽 目板張りで、残りは漆喰仕上げされ、コーニスはプラスター 仕上げ。断面図に示すように、炉棚飾りは大理石製で、木製 彫刻が施されている。また床は滑らかに仕上げたもみ材。大 階段は主要階から2階までなので、下階の家事室への出入り は、屋根裏まで達する裏階段による。」

と説明される。この案の場合、屋階が設けられているので、

「屋階の部屋は階高が内法で9フィートあり、椅子の高さまで 普通の羽目板張りで簡素な仕上げ。床は滑らかに仕上げたも み材で、炬棚飾りはポルトランド石製。」 と続いていく。そして解説は外観などに移り、

「この建物の正面は灰色のストック煉瓦で、田舎風飾りのつく コーニス、階段、扉の正面、慈台、台石はポルトランド石製 とされるであろう。ペディメントの装飾はスタッコ仕上げ。 その彫刻はポルトランド石製でとても高価となろう。建物は $24 \%$ スクエアからなり、上に記した手法では1スクエア当た り150 ポンドで仕上げられるので、総工費は 3,712 ポンド 10 シリングとなる。」

と終わる。このように、最後は必ず建設費に言及される。建設費は 100 平方フィートに相当する「スクエア」を単位面積として、1ス クエア当たりの工費と面積を掛けて算出された值である。面積には 解説の冒頭で述べられた建設規模が援用されており、積算には階数 が含まれないことになる。しかし、同じ建物種別では、かなりの場 合、スクエア数や主要階の階高の大きなほうが単価が高い。そこで 工費の単価は、仕上げの方法とともに、建物の規模も反映するよう に、主要階の面積だけでなく階高も考慮に入れながら、ある程度調 整していたように思われる ${ }^{21}$

解説は基本的にこうした内容と構成をもっていた。設計案として 扱われた建物は、この例の都市の住宅や、あるいは田舎の屋敷のよ
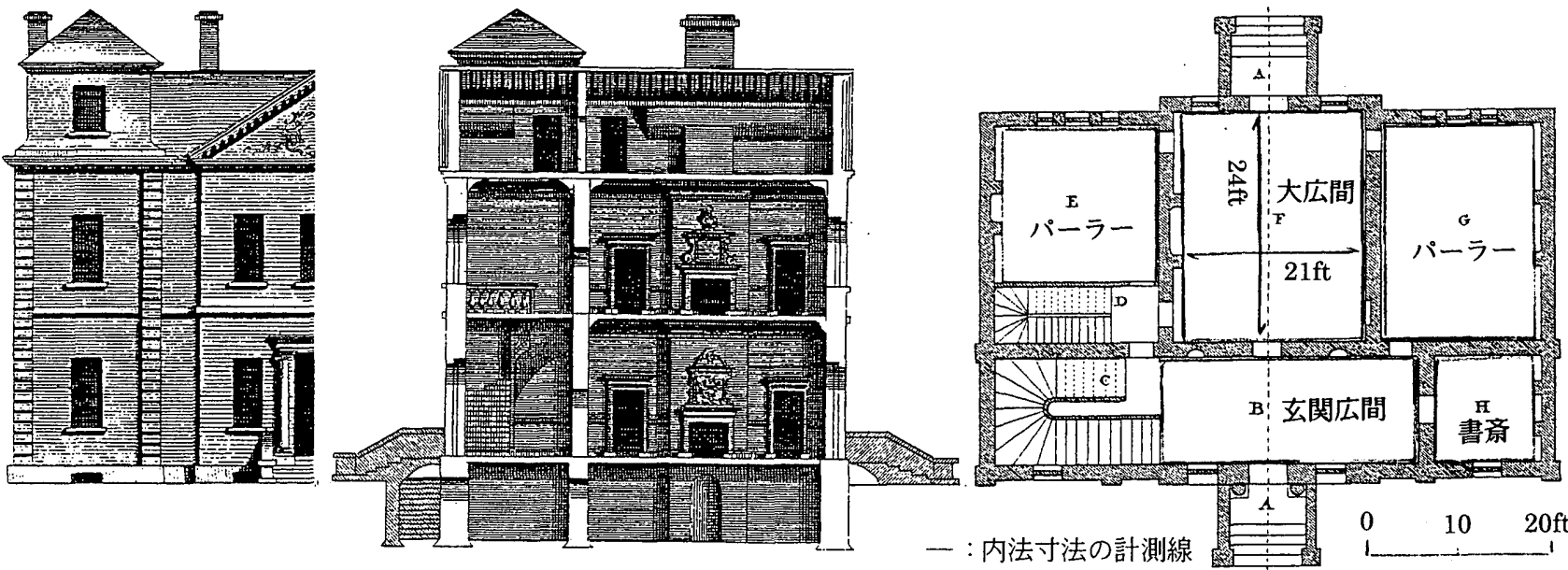

図·1 ウィリアムの第14案の立面図、断面図、主要階平面図 
うにその種別と立地が明確に述べられた場合と、家事室または住宅 と単に用途のみが記された場合がある。そこで、建物規模と解説の 文脈から整理してみると、田舎屋敷、東屋、小家族用の住宅、都市 の住宅という4つの建物種別にわけられ 22 、設計者とその種別をま とめると、表-1のようになる。また、多くの設計案で言及された階 高と建設単価についてみておくと、階高は地下階で7 9 フィート、 主要階（1階）で9 15フィート、上階で8 14フィート、屋階で7 10 フィートとなる。階ごとに較べると、1階が最大で、上階はそれ に等しいか小さく、地下階と屋階はほぼ等しく最も低い。また建物 種別からみると、田舎の建物のほうが都市の建物より全般に階高は 大きい。一方、建設単価は、全体の価格の幅は20 200ポンドとな

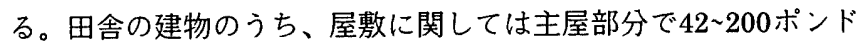
で、家事室などでは20 35 ポンドとなる。一方、都市の建物では 40 150ポンドとされていた。住宅の場合、単価の上限は田舎の建 物のほうが高く設定されている。しかし、前述したようにこの単価 には主要階である1階の規模も関係し、大きさが同じような田舎と 都市の建物を較べると、この単価もほぼ同程度となっていた ${ }^{23}$ 。

建物の意匠は、オーダーのある場合、ない場合をとおして、古典 主義様式が中心である。しかし、明確にバラーディオ風の要素をも つ例は必ずしも多くない。J.ヘイプニーではパラディアン・ウイン ドゥや浴場空のような英国パラーディオ主義的構成が目立つが、へ イプニーはむしろバロックやマニエリスムを想起させる表現を採る ことがあり、ライトラーでは尖りアーチや胸壁など中世風の要素も みられるからである24。

つぎに第三部をみると、本文は 2 頁で、図版 21 枚があてられてい る。21枚の内訳は、炉棚飾り4枚、悹2枚、階段室回り2枚、部屋の 展開5枚、スクリーン1枚、天井仕上げ2枚、天井とアルコーブ装飾 1枚、トラス屋根の構法2枚、鳩小屋1枚、門1枚となる。このうち ライトラーは、炉棚飾りなど11枚を考案し、ヘイプニーはトラス 屋根、鳩小屋、門を担当していた ${ }^{25}$ 。第三部の記述は第二部に較べ ると簡略で、図版のテーマのみが述べられるだけである。図版も立 面図や展開図を示すことを基本としていた ${ }^{26}$ 。しかしトラス屋根に 関しては、スパンから5つの場合にわけ、断面の形状や使用される 部材の寸法など、その構法が具体的に述べられていた ${ }^{27}$ 。屋根を除 く各案の意匠的特徵をみると、建物よりも多様な様式が認められる。 空回りでは、古典的であってもパラーディオ風からギッブズ風まで あり、中国趣味のものやロココ風と中国風の組み合わせもみられる。 とくにライトラーの場合には、ロココ風や中国風が目立っていた。

『当世建築業者の手引き』は、建物や装飾的部分の実例の集成で ある。実例集といっても、実際に建設された作品をまとめたり、建 築家が自らの設計案を集めたりした作品集とは異なり、本書は雊型

\begin{tabular}{|l|l|l|l|l|}
\cline { 2 - 5 } \multicolumn{1}{c|}{} & $\begin{array}{l}\text { 田舎 } \\
\text { 屋敷 }\end{array}$ & 東屋 & $\begin{array}{l}\text { 小住 } \\
\text { 宅 }\end{array}$ & $\begin{array}{l}\text { 都市 } \\
\text { 住宅 }\end{array}$ \\
\hline John Halfpenny & 8 & 2 & 0 & 0 \\
\hline William Halfpenny & 9 & 2 & 2 & 1 \\
\hline Timothy Lightoler & 6 & 0 & 0 & 0 \\
\hline Robert Morris & 2 & 0 & 0 & 4 \\
\hline
\end{tabular}

表·1 各設計者の設計案の内訳
集と呼ばれるものの一例である。雛型集とは、「理想的な、あるい はこれまでに試されたことのない設計案の集成」であり、「読者の 選択を助ける」出版物で ${ }^{28}$ 、著者も著名建築家よりも、本書のよう に建築著述家や実務的な建築家の場合が多い。取りあげられる対象 も、本書の第二部のように建物であったり、第三部のようなディテ 一ルのこともある。この種の出版物が本格的に世にでるようになっ たのは、本書も刊行される18世紀中頃からで、先にあげたラング リやモリスなども重要な著者であった。こうした出版物をみると、 例えばダニエル・ギャレット（Daniel Garrett, -1753）の『農家の 設計と見積り』（ロンドン，1747）では、家屋の設計方法の規則 化が図られ建設費に言及されているが、対象は農家に関連した建物 で、様式的にもパラーディオ主義の傾向が強かった ${ }^{29}$ 。また、モリ スの『建築備忘録』（ロンドン，1751）は東屋風の建物案が中心 で、意匠には多様性が採り入れられているが、おもに外観と平面で、 建設費用などには触れられていない ${ }^{30}$ 。一方、『建築四書』の翻訳 者でもあるウエアは『建築全書』（ロンドン，1756）という大部 の建築書を著した。そのなかで、雛型集ほど多数ではないものの、 やはり都市住宅からカントリー・ハウスなどの住宅の設計案を載せ ているが、室内の仕上げについて材料や工法などの具体的な記述は 充分ではなかった ${ }^{31}$ 。

『当世建築業者の手引き』では、都市や田舎の住宅をはじめいく つかの建物の種類をあげ、単に平面図、立面図を載せるだけでなく、 断面図と記述をとおして室内の仕上げまで理解できるように工夫さ れている。細部の図面集も意匠的な図面にとどまらず、トラス屋根 の構法や鳩小屋なども採りあげられていた。建物ならびに細部の様 式では、パラーディオ主義的な構成もみられるが、バロックやマニ エリスム的な傾向と、さらに中世風や中国趣味も採り入れられてお り、その幅は多様にされている。このように、『当世建築業者の手 引き』は読者のさまざまな要望を考え、かつ建設費の目安を示して いたように実用性にも配虑した内容となっている。とくに、意匠に ついては、18世紀中頃まで主流であったパラーディオ主義にとど まらない指向が認められるのである。

\section{§ 3. 建物設計案の分新-1. 平面と比例について}

設計案の平面は、一室構成の場合をのぞけば、さまざまな寸法を 与えられた多くの部屋から形成されている。けれども、実寸法は極

\begin{tabular}{|l|l|}
\hline $1: 1$ & $\begin{array}{l}4^{\prime} 6^{*} 4^{\prime} 6,5^{*} 5,6^{*} 6,6^{\prime} 3^{*} 6^{\prime} 3,7^{*} 7,8^{*} 8,8^{\prime} 6^{*} 8^{\prime} 6,9^{*} 9, \\
10^{*} 10,10^{\prime} 6^{*} 10^{\prime} 6,11^{*} 11,11^{\prime} 8^{*} 11^{\prime} 8,12^{*} 12,12^{\prime} 6^{*} 12^{\prime} 6,\end{array}$ \\
& $\begin{array}{l}13^{*} 13,13^{\prime} 4^{*} 13^{\prime} 4,13^{\prime} 6^{*} 13^{\prime} 6,14^{*} 14,15^{*} 15,16^{*} 16, \\
17^{*} 17,18^{*} 18,19^{*} 19,19^{\prime} 6^{*} 19^{\prime} 6,20^{*} 20,22^{\star} 22,23^{*} 23, \\
26^{*} 26\end{array}$ \\
\hline $3: 2$ & $\begin{array}{l}5^{\prime} 6^{*} 3^{\prime} 8,7^{\prime} 6^{*} 5,9^{*} 6,12^{*} 8,15^{*} 10,18^{*} 12,21^{*} 14,24^{*} 16, \\
30^{*} 20\end{array}$ \\
\hline $5: 4$ & $5^{*} 4,10^{*} 8,12^{\prime} 6^{*} 10,15^{*} 12,17^{\prime} 6^{*} 14,20^{*} 16,25^{*} 20$ \\
\hline $2: 1$ & $8^{*} 4,10^{*} 5,12^{*} 6,14^{*} 7,19^{*} 9^{\prime} 6,20^{*} 10,24^{*} 12$ \\
\hline $6: 5$ & $6^{*} 5,9^{*} 7^{\prime} 6,15^{*} 12^{\prime} 6,18^{*} 15,24^{*} 20$ \\
\hline $4: 3$ & $8^{*} 6,10^{*} 7^{\prime} 6,12^{*} 9,18^{*} 13^{\prime} 6,24^{*} 18$ \\
\hline $3: 1$ & $12^{*} 4,15^{*} 5,18^{*} 6,21^{*} 7,33^{*} 11$ \\
\hline
\end{tabular}

表-2 5種類以上繰り返し抽出された比とその実寸法 
めて多岐におよぶものの、幅と奥行きのなす比として捉え直してみ ると、設計案の間や、設計者同士で共通する比の採用がみられるな ど、比から整理することが可能と思われる。作品解説には比に関す る言及はないが、多様な寸法を比という視点から分析することをと おして、平面構成について検討してみよう。採りあげる部屋は、居 間や寝室など室名が明らかな空間で、階段室や玄関前のホールや、 閉じられた通路も対象とした ${ }^{32}$ 。解説の寸法は部屋内部の壁面間の 距離が採られているので、分析は部屋の内法寸法とし、図面と記述 で確認できる場合とし、記述にはないが図面には明瞭に示され計測 できる場合も含めた。

抽出できた比は1:1から13:2まで136であった。このうち、1:1や 3:2 のように、ひとつの建物でも、あるいは異なる設計案の間でも 繰り返しみいだされた比は62が数えられた。残りは、ひとつの比 例にひとつの寸法が対応し、一度のみ使われる場合であった。何度 も抽出された比では $1: 1$ が最も頻繁に表れ、建物種別や設計者に関 わらず採用されていた。ほぼすべての建物種別で検出された比には、 1:1のほかに12:11、5:4、3:2 があり、またすべての設計者に共通 する比には、 $5: 4 、 3: 2$ と11:10 があげられる。136の比の分布をみ ると、1:1 から $3: 2$ の間に $73 、 3: 2$ と $2: 1$ の間に $24 、 2: 1$ と $3: 1$ の間に $23 、$ $3: 1$ より大きい比は 16 となる。したがって、抽出された大半の比は 1:1から3:2の間にあったといえる。

ついで実寸法に対する比の関係という点から、比と部屋の大きさ、 すなわち幅と奥行きの寸法の対応関係について検討してみよう。繰 り返し抽出できた比について整理してみると、1:1の比には4 4 フー ト6インチ平方から 26 フィート平方まで、28の大きさが対応する。 こうして多様な寸法に適用された比をみると、1:1以外では 9 種の大 きさに対応する $3: 2 、 さ ら に 7$ 種の大きさに対応する $5: 4$ と $2: 1$ など があげられ、5種以上の対応関係のみいだされた比をまとめると表 -2のようになった。また、同じ建物において、ひとつの比に対して 一定の寸法が適用されることもあり、最も多い場合では7:6の比に $14 \times 12$ フィートが 4 回用いられていた。比には1:1のような簡単な 整数同士の比から、2桁さらに3桁の整数を含む比が抽出された。 全体的にみて、簡単な整数比では寸法の最小単位は6インチであっ た。一方、3桁の比など大きな整数の比となった場合をみると、最 小寸法は3インチ、7インチ、8インチ、9インチなどが採られてい ることが多い。しかし、3桁の数同士の比の場合でも、簡単な整数 比に近似させることはできる。すなわち、26フィート:15フィート 7 インチ $=312: 187 \fallingdotseq 5: 3$ という具合である。簡単な整数比をなす場 合、まず比を設定し、その比から寸法を割りだしても、あるいは適 切な寸法で割り付けても、部屋の大きさは容易に決定しうる。一方、 複雑な比となった場合、そうした比を当初から設定して設計したと 考えるのは妥当とはいえない。その場合、部屋の大きさは実寸法を もとに決定されたにちがいないことを、その比は示すと思われる。

つぎに、比と建物の種別の関係をみてみよう。田舎の建物からは 本書に表れた比のはとんどにあたる、1:1から13:2までの132の比が 抽出された。一方、都市の建物から取りだされた比は16で、大半 の12の比は1:1から26:17までにある。また両方の種別に共通した比 は12であった。都市の建物は若干の例外はあるが、1:1から $26: 17$ ま での、田舎の建物でもよくみいだされる比が適用され、平面が構成 されていた。田舎の建物はさまざまな用途に使われる多くの部屋を
もち、それに多様な寸法を当てていることが、この比の種類に示さ れている。それに較へてて都市の建物は、例自体が少ないとはいえ、 適用される比に範囲が設けられていたことが、田舎の建物よりも明 瞭といえる ${ }^{33}$ 。

一方、比を適用される部屋の点からみてみよう。部屋については、 玄関や階段室の前室 (ホール)、居間や食事室、広間（サルーン） などの接客用の部屋、寝室や書斎、衣裳室などの個人的な部屋、奉 公人が使用したり作業する部屋、収納用の部屋、そのほかの部屋や 通路空間にわけて整理した。1:1はこうした各種の部屋から抽出さ れる。一方、2:1より大きい比、とくに3:1より大きい場合、適用さ れているのは主として通路空間であった。前室や収納のための部屋 は1:1から3:1の範囲にあり、規模に多様さが認められる。また、接 客のための部屋と個人で使う部屋を較べると、接客用が $1: 1$ から $32: 19$ であるのに対して、個人の部屋は $1: 1$ から $5: 3$ とわずかだが範 囲が狭くなっている。他方、個人で使う部屋でも奉公人の場合には、 1:1から34:13とより大きな比、より奥行きの深い部屋まで適用され、 とくに5:4よりも大きいほうで多くなっていた。おもに個人が使う 部屋では、使い手により大きさに違いが与えられているといえる。

『当世建築業者の手引き』における部屋の平面と比の関係をまと めてみると、抽出された比は136で、このうち 62 の比が繰り返して 適用されている。これらの比のうち、1:1は寸法、部屋や建物の種 別によらず頻繁にみいだされ、適用しやすい比と捉えられていたと いえる。そのほかの比は、1:1ほど顕著に検出されてはいない。け れども、簡単な整数の比を組み合わせた比、例えば $3: 2 、 5: 4 、 2: 1$ などは、寸法あるいは回数で、ほかの比よりも多く抽出されている。 また、種類からみると $1: 1$ から $3: 2$ 範囲に大半の比があったことか ら、3:2までで簡単な整数の比が設計には有効性をもっていたとみ なすことができる。建物の種別からみると、都市の建物に適用され た比には限定された幅が認められる。簡単な整数比を繰り返し使う ことで、平面をまとめていく指向が、田舎の建物と較べて明瞭に示 されていたといえる。

\section{§ 4 . 建物設計案の分析 -11 . 建築家と比例について}

『当世建築業者の手引き』の建物設計案には、4人の考案者がい たことから、個々の建築家において比の使い分けに関していかなる 特色があるか、また比の適用にどのような特徵がみられるか、検討 したい。各建築家が担当した設計案の数と、その案から抽出された 比の数、ならびに範囲、また建築家相互で共通してみいだせる比の 数、ならびに繰り返し適用された比の数をまとめると、表-3のよう になった。

\begin{tabular}{|l|c|c|c|c|c|}
\cline { 2 - 6 } \multicolumn{1}{c|}{} & $\begin{array}{l}\text { 設計 } \\
\text { 案の } \\
\text { 数 }\end{array}$ & $\begin{array}{l}\text { 抽出さ } \\
\text { れた比 } \\
\text { 数 }\end{array}$ & その比の幅 & $\begin{array}{l}\text { 共通す } \\
\text { る比の } \\
\text { 数 }\end{array}$ & $\begin{array}{l}\text { 繰り返 } \\
\text { された } \\
\text { 比の数 }\end{array}$ \\
\hline J. Halfpenny & 10 & 66 & $1: 1 \cdot 16: 3$ & 26 & 30 \\
\hline W. Halfpenny & 14 & 52 & $1: 1 \cdot 13: 2$ & 26 & 35 \\
\hline T. Lightoler & 6 & 56 & $1: 1 \cdot 59: 10$ & 18 & 27 \\
\hline R. Morris & 6 & 12 & $1: 1 \cdot 13: 5$ & 8 & 11 \\
\hline
\end{tabular}

表-3 各設計者のから抽出された比の数と幅 
まず4人全員をとおして、抽出された比の特色を検討してみよう。 担当した設計案の数ではへイプニーが最多の14であるが、検出さ れた比の種穎については作品数で10のJ.ヘイプニーが66と最も多 い。モリスとライトラーは設計案の数は等しく6であるが、採用さ れた比はモリスの12に対して、ライトラーは56 と圧倒的に多くな っている。また、設計者相互に共通してみいだせる比についてみる と、適用された此の種頑が少ないとはいえ、モリスの場合、ほかの 設計者にも共通して認められる比がほとんどを占めているが、ほか の3人ではその割合が小さく、とくにライトラーの場合、かれのみ にみいだせる比が極めて多数にのぼった。共通する比をひきだせる 設計者の組み合わせをみると、J.ヘイプニーとヘイプニーのふたり にライトラーかモリスが加わることが多く、他方、ライトラーとモ リスという組み合わせは、全員に共通する比の場合をのぞけば、1 例のみであった。そして、使われた比の範囲をみると、すでに述べ たように、2:1より小さな比が多く、J.ヘイプニー、ヘイプニーと

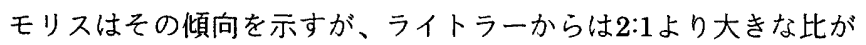
ほかの3人と較べるとより多くみいだされた。

つぎに各設計者についてみてみると、J.ヘイプニーでは同一の比 が綑り返し異なる寸法にあてられている。例えば、1:1は13回、5:3 が4回、4:3が3回などがあげられる。また、J.ヘイプニーは同一の 比を異なる種類の部屋に適用する傾向がある。すなわち、4回適用 されている6:5の比は、広間（サルーン）、奉公人用広間、納戸と いう具合である。一方、ヘイプニーもJ.ヘイプニ一同様、同一の比 を繰り返し異なる寸法にあてる。例えば、1:1は14回、5:4が4回な どである。設計者間に共通してみいだせる比や、使われる比や繰り 返し適用される比の点では、ヘイプニ一はモリスほどほかの建築家 と共通する比を採用することはないが、一方ライトラーほどの特異 性もみられず、いわば両者の中間的な位置にある。

ライトラーは、1:1をのぞき、同一の比、あるいは寸法を繰り返 し使う回数がほかの 3 人より少ない。すなわち、ひとつの比の採用 は一度、または比と寸法はひとつの対応関係、という比の適用方法 が目立っている。ライトラーの設計対象は、田舎の建物、とくに家 事室、作業場の多い建物が多く、それゆえさまざまな異なる大きさ の部屋を作る必要が、こうした適用傾向の理由といえる。また、ラ イトラーの作品から抽出された比では、簡単な整数のなす比が少な い反面、2行以上の整数の比、あるいは3桁の場合もある。これは 約数をもたない寸法を採用しているだけでなく、3インチ、7イン チなどの寸法の最小值も関係している。199:100は2:1、292:201で あれば $3: 2$ とうう近似值をもつことは確かである。しかし、こうし た比からみて、また比と寸法の対応から考えて、ライトラーは部屋 の規模を比よりも実寸法により決めていったことが推察される。と ころで、ライトラーは書名の頁で彫刻師として紹介されている ${ }^{34}$ 。 実際には建築家としても活動していたが、比較的中世風やロココ的 な傾向の目立つ作品を残している35。こうした指向が比を活用する、 いわば古典主義的な方法よりも、実寸法から割り付ける設計方法を 採ることになり、比として捉えると複雑な整数比となったといえる かもしれない。

モリスの設計案では、1:1と4:3の比をもつ寸法が採用された寸法 の4割を占め、その寸法の適用された部屋は6割にものぼった。ま た、1桁の簡単な整数比が抽出された比の半数以上となっている。
平面の決定に関して、モリスは比を実寸法に先行して活用している ように思われる。さらに、高さを考慮に入れると、モリスの設計案 からは1:1:1という立方体の部屋がみいだせる。類似する例には 3:3:4の場合があるだけで、決して多くはなく、担当した建物は都 市の住宅がほとんどであった。しかしそうした限定はあるものの、 提案された設計では、比が寸法決定に重要な役割を担っていたこと が明らかである。

各設計者で考案した建物の種別に違いがあるとはいえ、ライトラ 一では、複雑な整数を含み析数も多い、多様な比が採用され、ひと つの比に寸法を複数あてることが少なかった。つまり、比は寸法の 決定や部屋の割り付けで、重要とみなされていないといえる。他方、 モリスは簡単な整数比を主体に平面を割り付けていた。モリスは比 例について取り扱った著畫もあり、ルネサンス以来の古典的比例論 につうじていたことが 35 、比をもとに部屋の構成を考えた設計方法 に結びついたと考えられる。この二人に較べると、J.ヘイプニーと ヘイプニーは、抽出された比の特色が明瞭ではない。比は平面分割 の手法として利用されているが、モリスのように比自体に意味づけ のされた使いかたはされていなかったといえる。

\section{おわりに}

『当世建築業者の手引き』は、構成と内容からみて、雛型集、と りわけ建物設計案の集成が核となるように編集されている。しかし、 単に図面を集めただけではなかった。オーダーについての記述は、 翻訳をあてているものの、記述が容易に理解でき、かつ論点が把握 されやすいような文章表現がとられていた。へイプニーはオーダー が「最も有能でかつ経験を積んだ」建築家にとって慣習であるとす るが、本書の読者は数多くの建築書を熟読する機会はないであろう とみている ${ }^{37}$ 。この本は、「建築を熟知した者には有用で、初心

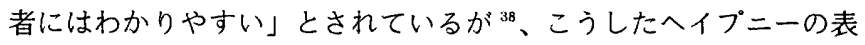
現から、いわゆる建築家というよりも、むしろ建築職人や建設業者、 あるいは建物の依頼者を読者として想定していたといえる。しかし、 建築術という知識の領域はきわめて広範であり、「最も豊かな才能 に恵まれた人に専心する余地がまだ残されている」 ${ }^{39}$ とへイプニー は考えていた。こうした意図が、単なる雛型を数多く提示するため の図面集成というだけでなく、オーダーも採りあげたこの構成に表 れたといえよう。

図面の解説では、室内の仕上げまで言及されているとともに、建 設費についても触れられており、建物の内容が具体的に理解できる ように意図されている。こうした点にも、ヘイプニーが想定してい た読者層がうかがわれる。また著者が4人であったというだけでな く、その4人の意匠と構成の手法は互いにかなり異なる面ももって いた。意匠的にみれば、18世紀前半に主流であったパラーディオ 主義的なものから、マニエリスムやバロック的表現、さらに中世的 な趣をもつものもあった。18世紀中頃には、パラーディオ主義か ら新古典主義への移行が端緒につくことが知られている ${ }^{10}$ 。この傾 向の拡がりは、すでに本書にも現れているといえる。また、平面構 成の基礎である部屋を比から分析してみると、ルネサンス以来の古 典的比例諭に依拠する比を採用し平面をまとめている案から、比を 割り付けの手段としているもの、さらに比ではなく実寸法により割 り付けていると考えるほうが妥当な設計案もあった。さらに、繰り 
返し抽出された比では、1:1、4:3、3:2また $2: 1$ のうに古典的比例 論で言及される比だけでなく、6:5や5:4のようにそこで取りあげら れない比もあった ${ }^{4}$ 。ここにも、ルネサンスの古典主義との差異が 指摘できるであろう。

このように、『当世建築業者の手引き』は、単なる雛型集にとど まらず、比例と意匠の両面から、18世紀の前半から中頃への英国 における建築的動向を明瞭に反映した内容が特徴といえる。

\section{註と参考文献}

1) Colvin, Howard, A Biographical Dictionary of British Architects 1600-1840, New Haven and London, 1995, pp.446-448.

2) Harris, Eileen et als., British Architectural Books and Writers 1556-1785, Cambridge, 1990, p.218.

3）書名部分は, The Modern Builder's Assistant; Or, a Concise Epitome of the Whole System of Architecture. 本稿では， L. H. Fowler et als., The Fowler Architectural Collection of The Johns Hopkins University, Baltimore, 1961 (武蔵野美術大学蔵)のマイクロ・フィルム版を 用いた．出版年には，MDCCVLII の解釈で，3とおりの見解がある.

(1) MDCCXLIIを1742年とする説，Fowlerの前掲畫，p.125.

(2) MDCCVL + II として1747年とする説，H.·W. Kruft, A History of Architectural Theory, London and New York, 1994, p.244.

(3) MDCCLVIIとして1757年とする説, Colvin とHarrisの前掲書. なら びに, T. Archer, The Literature of British Domestic Architecture 1715-1842, Cambridge, Mass. and London, 1985, p.404. 以上の検討から，(3)を妥当と考え，本稿では1757年と判断した

4) Wittkower, Rudolf, Palladio and English Palladianism, London, 1983, pp.88-89.

5）ヘイプニーは1751年にパラーディオの『建築四書』の第一書の翻䛊を出 版したが，本書に納められた翻訳はこれとは異なる.本書の翻訳のほうが 原著にしたがっているとされ，また図版は，「コレン・キャンベル版のパ ラーディオの第一書からオリジナルの銅版の図版」であった. Harris， op.cit., p.221.

6）桐數真次郎編著，『パラーディオ「建築四書」注解』，東京，1985,p.507.

7）例えば，地の文に対して，文頭を落として書かれた插入的な文章ではすべ ての文字をイタリック体としている.

8）キューマティウムなどの単語をウィリアムは英語で記すことが可能であっ た.こ㧈らの単語の建築に関する英語文献の初出をみると, cymatium, 1563, plinth, 1611, cincture, 1696, astragal, 1563 と, どの単語もす でに英語で使われていた（OEDによる).

9) Halfpenny, op.cit., p.3, p.7.

10) Ibid., p.1.

11) Ware, Isaac, The Four Books of Andrea Palladio's Architecture, Lon don, 1738, (reprint ed., New York, 1965, p.11)

12）桐敷前掲書，p.507.

13) Halfpenny, op.cit., p.18.

14) Ware, op.cit., pp.21-22.

15) Halfpenny, op.cit., the title page.

16）ライトラーは, ヘイプニーとモリスの死後、本書の編箱を任される立場に あり，図版を数枚加えたとされる. Colvin, op.cit., p.617

17）モリスに関しては，3住戸からなる連続住宅を設計しており（図版44）。 こ れを3として数えている.

18） Halfpenny, op.cit., pp.30-31, pls.36-37. 以下の引用はすへてこの部分 からである

19） AAという表記は本書のままである. 階段が 正面と背面にあることから, 本来は，'A，A'と書かれるべきであったと思われる．

20）各階に対してへイプニーが当てた用語には，つぎの日本語を対応させた the parlour story (the principal floor) : 主要階，1階，地上階 the cellar story (the lower offices): 地下階. the chamber floor : 上階 (2ないし3階). the attick story (the garetts): 屋階.

21）スクエアは，床面積やタイル張りの面積などを計測する単位で，1スクエ ア $=100$ 平方フィートとなる. 田舎の建物の場合, 単価の高い例をみると, 62.25スクエアで200ポンド（階高15フィート），27.125スクエアで150 ポンド（階高14フィート），33スクエアで145ポンド（階高17フィー ト），24.5スクエアで140ポンド（階高15フィート），36スクエアで100 ポンド（階高15フィート），26.5スクエアで100ポンド（階高13フィー ト）となる. 若干の例外もあるが，この傾向は読み取机る. また，仕事場 や家事室が主となる建物ではこの単価は安くなったり，必ずしもすべてが この原則ではなかった

22）アーチャーは全部で29案とし，田舎屋敷 14，東屋6，住宅5，町屋敷2，低 層の建物と田舎に建つ建物各1としていた. Archer, op.cit., pp.404-405. この分類では，住宅の内容が不明である．また3戸としたモリスの都市住 宅をひとつと数えても，33は数えられる.したがって，この区分には疑問 が残る。本稿では, 'house'という表現の建物は「小家族用の建物」に分類 し，都市の住宅は町屋敷と連続住宅を含めることにした。

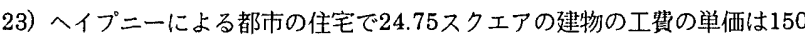
ポンド，24.5スクエアの田舎屋數は140ポンドであった

24）図版30のヘイプニーによる田舎の敷地に建つ邸宅は，中央部分が後退し て屋根は高くなり，隅石の強調さ机たいわばマニエリスム風の外観をも つ. また図版59のライトラーによる田舎の作業場の建物では，尖頭ア一チ と䏩壁，ロンバルディア帯を備えており，中世風というべきものとなって いる.

25）細部図面集では，この15枚以外には考案者の署名がなく，図版作成者の名 のみが記されていた。

26）階段回りの壁面装飾のための図版71，72のみ，平面図も描か㧈ていた

27）図版82に4図示されたトラス屋根は，スパンが16，24，30，17フィートの 場合で，図版83では50フィートであった．解説にはおのおのの屋根に採 用される屋根部材の寸法が述べられ，組み立てかたが説明さ㧈ていた。

28) Harris, op.cit., p.34.

29) Ibid., pp.203-204. 書名は, Designs and Estimates of Farm Houses.. なお，ギャレットはパラーディオ主戔を推進したバーリントン卿の下で活 動した建築家のひとりとして知られる. Colvin, op.cit., p.393.

30) Harris, op.cit., pp.319, 322. 書名は, Architectural Remembrancer. および，拙稿「ロバート・モリス著『建築備忘録』の基礎的考察」，研究 紀要 1 , 前橋, pp.45-49

31）畫名は, A Complete Body of Architecture. ウエアはその第 III書 (pp.273-436)のなかで，30枚以上の図版とともに，種々の住宅を取りあ げ, とくに平面計画や外観の意匠を述べている.

32）分析対象は図面と記述のある場合なので，2階が1階と同じ間取りである という記述のみで2階の部屋に言及されても数に含めていない.また長く 折れ曲がりの続く通路や中庭の場合は，対象に含めていない．

33）都市の建物案の場合，ヘイプニーもモリスも建物の外形はほほ矩形として おり，田舎の建物と較べると平面棈成の自由度は小さく，それが使用され る比の範囲にも影響したとみなされる。

34) Halfpenny, op.cit., the title page.

35) Colvin, op.cit., pp.617-618.

36) Wittkower, Rudolf, Architectural Principles in the Age of Humanism, New York, 1965, p.145

37) Halfpenny, op.cit., p.i.

38) Ibid.

39) Ibid.

40) Summerson, John, Architecture in Britain 1530 to 1830, Harmondsworth, 1970, pp.407·408.

41) Funari, Michele, Formal Design in Renaissance Architecture, New York, 1995, p.184.

なお、使用した図版は王立英国建築家協会図書室所蔵の復刻本のコピーをもと に、筆者が加筆したものである。また、本諭考は、平成9年度文部省科学研究 貫補助金基盤研究（C）（課題番号 09650708）の一部をなすものである。

（1999年11月1日原稿受理，2000年 5 月22日採用決定） 